\title{
Honore de Balzac, La Peau de chagrin
}

\section{Lise Sabourin}

\section{(2) OpenEdition}

\section{Journals}

\section{Édition électronique}

URL : http://journals.openedition.org/studifrancesi/34857

DOI : $10.4000 /$ studifrancesi.34857

ISSN : 2427-5856

\section{Éditeur}

Rosenberg \& Sellier

\section{Édition imprimée}

Date de publication : 1 novembre 2005

Pagination : 430

ISSN : 0039-2944

\section{Référence électronique}

Lise Sabourin, «Honore de Balzac, La Peau de chagrin », Studi Francesi [En ligne], 146 (XLIX | II) | 2005, mis en ligne le 30 novembre 2015, consulté le 19 avril 2021. URL : http://journals.openedition.org/ studifrancesi/34857 ; DOI : https://doi.org/10.4000/studifrancesi.34857

\section{Ce document a été généré automatiquement le 19 avril 2021.}

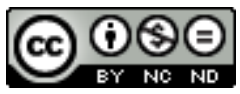

Studi Francesi è distribuita con Licenza Creative Commons Attribuzione - Non commerciale - Non opere derivate 4.0 Internazionale. 


\title{
Honore de Balzac, La Peau de chagrin
}

\author{
Lise Sabourin
}

\section{RÉFÉRENCE}

HONORE DE BALZAC, La Peau de chagrin, dossier par GUILLAUME KICHENIN, lecture d'image par ALAIN JAUBERT, Paris, Gallimard, 2003 («Folioplus classiques»), pp. 377.

1 Cette édition scolaire, sans notes ni préface, offre en revanche un dossier permettant de situer rapidement le roman balzacien de 1831 dans le contexte romantique comme par rapport à la biographie et à la personnalité de son auteur. Quelques textes antérieurs (suggérant de voir Raphaël en anti-Rousseau ou en nouveau Candide), contemporains ou ultérieurs (extraits de Melmoth de Mathurin, du Portrait ovale de Poe et du Portrait de Dorian Gray de Wilde) peuvent inciter des élèves à réfléchir sur le fantastique le roman philosophique ou l'autobiographie (que l'analyse du Désespéré de Courbet, datant de 1843 , voudrait, assez artificiellement, corroborer). 